\title{
SEATED CLAY FIGURINES FROM THE NEOLITHIC PERIOD, ISRAEL
}

\section{Tamar Noy}

Although early literary texts and documents as well as archaeological discoveries attest to the existence of fertility cults in antiquity, the identification of these cults in prehistoric periods still presents a problem (Ucko 1968; Cauvin 1972). The existence of such cults may, however, be seen in the abundant human and animal figurines in wall paintings, rock carvings, and significant groupings of particular objects. The carved bone sickle handles from the Natufian culture $(10,300$ - 8600 B.C.E.), for instance, could be interpreted as objects in fertility ceremonies by their combination of the sickle and the animal carved on the handle, which may represent the two kinds of food consumption - that of cereal crops and animal flesh.

During the Neolithic in the Levant (8200 - 4500 B.C.E.), fundamental and far-reaching changes took place, both in everyday life and in the social and religious aspects of society. It was in fact the achievements of the preceding Natufian culture which brought societies in this area to the threshold of the Neolithic revolution. Intensive research in Israel has brought to light rich material from the cultures which existed during the transition from the Epi-Paleolithic to the Neolithic, giving us even so but a fragmentary picture of the end of this period.

Among the principal changes characteristic of the Neolithic are the existence of large-scale settlements, the growth of population, and the dependence on early farming: all these were already present in the Pre-Pottery Neolithic A period (8200 - 7600 B.C.E.). Advance in farming life, changes in house shape, the development of crafts such as plaster-making, basketry, weaving, the use of flax fibres for textiles, and the increased trade in asphalt, obsidian, sea shells and semiprecious stones are well attested in the Pre-Pottery Neolithic B (7600 6200 B.C.E). Particularly striking is the presence of numerous artistic and cultic objects. These include both male and female human figurines of various shapes and sizes, masks and plastered skulls. This overwhelming amount of human representation suggests the possibility that men visualized their gods in their own image. Temples were built for the performance of cultic rituals, and mythological scenes were depicted on walls, as can be seen at Çatal Hüyük in Anatolia. 
In spite of the fragmentary nature of the archaeological evidence from the sixth millennium, many pottery figurines are known from this period, appearing at the same time as the earliest pottery known. ${ }^{1}$ Also at this time, the increasing scale of settlements and their locations indicate advances in agriculture.

During the fifth millennium, settlement spread into now arid parts of the country, taking advantage of an improvement in the climate. Local cultures of this period - some show a transition to the Chalcolithic - are known mostly from their pottery design and repertoire. Well-established settlements in fertile valleys indicate a heavy reliance on agriculture. The arid area has provided us with a unique example of an isolated temple, with an extraordinary representation of leopards outlined with small stones in front of the building as if guarding it.

The seated human figurines, found among other human representations, are known from as early as the early Neolithic. Their seated posture may represent the moment of giving birth - the mother goddess - or a combination of this and a goddess enthroned. The earliest known figurines are from Netiv Hagedud, the Sultanian phase of the PPNA (Bar-Yosef and Gopher, personal communication) ${ }^{2}$ and Jericho (Kenyon and Holland 1982 a). These figurines are small, and their upper bodies are very stylized (Fig. 1) ${ }^{3}$ No details of the limbs or features are shown, except for the eyes and small breasts. The lower part of the body is more detailed, two legs are shown, and a groove divides this part into two sections. The possibilities of iconographic comparison are very limited.

Although the PPNB in Israel has been so well documented, almost no seated clay figurines have been found. The few that were found in Jericho are a continuation of the previous culture's style (Kenyon and Holland 1982 b). However, the figurines found in other parts of the Levant from various phases of the PPNB demonstrate a new type: they are larger; most of the body elements, such as the breasts and belly, are well pronounced; and the lower part of the body is exaggerated. Although the head is still very stylized and the hands are not always represented, the image of this type of figurines is well established. ${ }^{4}$

Numerous well defined seated figurines are known from the Yarmukian culture of the sixth millennium B.C.E. The Kefar Giladi figurine may be the earliest of this period (Fig. 2) (Kaplan 1957-8). They are all made of the same clay as the vessels of the period. These 
figurines are more detailed, with certain elements receiving additional emphasis. Most of them are covered with red paint. The majority of these figurines were found in Sha'ar Hagolan (Stekelis 1972) (Fig. 3-4) ${ }^{5}$ and H. Minha (Munhata) (Perrot 1967) (Fig. 5, Plate 6) ${ }^{6}$, both sites in the Jordan Valley. In addition, a few have been found inland and on the coast. Such figurines are also known from Syria and Lebanon.

A special technique was employed to make these figurines: on a cylindrical core layers of clay were added for the main parts of the body. The entire figurine was then completed by a few more incisions, clay pellets and paint.

The naturalistic style together with the symbolism (including the use of red paint) are characteristic of the unique iconography of this type of figurine. The legs are divided into two parts, and the buttocks are steatopygous - this may have been the natural form, or may have been used to emphasize the seated position. The belly and breasts are clearly represented. One arm runs along the body, and the other is placed under the breasts. A "garment" covers the shoulders and the entire back, where it is divided into two parts. The head is triangular, wide at the bottom and usually pointed at the top. Hair dress is shown on the back of the head, which arches slightly backwards. The eyes, cheeks, ears and probably earrings were added at a later stage. It should be noted that only on two faces, both from Sha'ar Hagolan, was a mouth added. While we are still dealing with the details, the characteristic "coffee bean" or "lizard" eyes should be mentioned. They are elongated and narrow at both ends and grooved in the middle. Their oblique setting gives the face a particular form, perhaps recalling grains on a stalk (Noy 1984). The nose is prominent, and continues to be shown in this manner into the Chalcolithic.

Very few figurines had any additional features except for the "garment" - a ritual costume - hair and earrings. One example has animals depicted by means of incisions on the lower part of the head (Kaplan 1972) (Fig. 6). There is also a "seated figurine wearing a soutane and mask" (as it was described by Yeiven and Mosel 1977). However, no stools/thrones have been found in archaeological excavations. The importance of such stools or thrones can be seen at Çatal Hüyük, where the stool is emphasized by its size and by the depiction of two felines, one on either side of the goddess seated on it (Múllàrt 1967).

In the fifth millennium almost no pottery figurines are known until now, while the Chalcolithic period, in the fourth millennium B.C.E. is represented by an anthropomorphic vessel. 
To summarize: we can observe that the seated figurines made of clay are known from the beginning of farming in the Early Neolithic period of the early eighth millennium B.C.E. Their posture and the cultural context of their appearance suggest their connection with fertility cults. In the course of time, the symbolic language they exemplify becomes more elaborate.

\section{Notes}

1 Clay is known as a raw material for the modelling of figurines as early as the beginning of agriculture. Clay figurines can be more expressive and skilfully modelled than those of stone, which are known even earlier.

2 The figurines, of which the complete one is $42 \mathrm{~mm}$ high, were found in the Excavations of Netiv Hagedud (Lower Jordan Valley), directed by O. Bar-Yosef and A. Gopher from the Institute of Archaeology, Hebrew University and sponsored by the National Geographic Society, Washington D.C.

3 Figures $1-3,6$ were drawn by F. Vainer.

4 Ain Ghazzal in Jordan (Roliefson 1985), Aswad Hil-11 in Syria (Contenson 1985), Mureybet in Syria (Cauvin 1977).

5 Figure 4 from Sha'ar Hagolan is shown here for the first time. Fig. 3 is after Stekelis 1972: pl. $49,1$.

6 The drawing is after Cauvin 1972: fig, 29:1. Height: $10 \mathrm{~mm}$. 
Bibliography

CONTENSON, H. de

1985 - Early Agriculture in Western Asia, Studies in Ancient Oriental Civilization 36, pp. 57-59.

CAUVIN, J.

1972 - Religions Néolithiques de Syro-Palestine, Paris.

1977 - Les fouilles de Mureybet (1971 - 1974) et leur signification pour les origines de la sédentarisation au Proche Orient, Annual American School of Oriental Research 44, pp. 19-47.

KAPLAN, J.

1957-8 - The Excavation in Kefar Giladi in 1957, Bulletin of Israel Exploration Society XXII:1, pp. $92 \mathrm{ff}$.

1972 - The Archeology and History of Tel-Aviv Jaffa, Biblical Archeologist 31, pp. 68-69.

KENYON, K.M. and HOLLAND, T.A.

1982 a - Excavations at Jericho Vol IV, London, fig. 223/1.

1982 b - Ibid. fig. 223/3.

MELLART, $\mathbf{J}$.

1967 - Çatal Hüyük - A Neolithic Town in Anatolia, London.

NOY, T.

1984 - Female figurine, Highlights of Archeology, the Israel Museum, Jerusalem, pp. 26-27.

PERROT, J.

1967 - La Palestine Préhistorique, Munhata Un Village Préhistorique, Bible et Terre Sainte 39, pp. 4-17.

ROLEFSON, G.O.

1985 - The 1983 Season at the Early Neolithic Site of Ain Ghazal, National Geographic Research Vol. 1, pp. 44-62.

STEKELIS, $M$.

1972 - The Yarmukian Culture of the Neolithic Period, Jerusalem.

UCKO, P.J.

1968 - Anthropomorphic Figurines, London.

YEIVIN, E. and MOZEL, I.

1977 - A "fossile directeur" figurine of the Pottery Neolithic A, Tel Aviv 4, pp. 194-200. 